\title{
The Effects of Mentoring Functions on Career Adaptabilities and Career Self-Efficacy: the Role of Career Optimism
}

\author{
Assoc. Prof. Dr. Selahattin KANTEN \\ Canakkale Onsekiz Mart University, School of Applied Sciences at Biga, Canakkale, Turkey \\ Assoc. Prof. Dr. Pelin KANTEN \\ Canakkale Onsekiz Mart University, Faculty of Political Science, Canakkale, Turkey \\ Funda ÜLKER \\ Instructor, Namık Kemal University, Hayrabolu Vocational School, Tekirdağ, Turkey
}

\begin{abstract}
This study aims to investigate the effects of mentoring functions on undergraduate student's career adaptabilities and career self-efficacy levels and the mediating role of career optimism. It is suggested in the literature that some factors stimulate student's career adaptability levels. Therefore, mentoring functions, career optimism and career self-efficacy are considered as predictors of career adaptabilities within the scope of the study. Accordingly, data which are collected by the survey method from 311 undergraduate students having an education on different field such as business administration, international trade and logistics, public management and labor economics are analyzed by using the structural equation modeling. The results of the study indicate that mentoring functions, which is labeled as role modeling, have significant effects on student's career adaptability, career optimism and career self-efficacy levels. However, it has been observed that career optimism has a significant effect on career self-efficacy and career adaptabilities. On the other hand, it is seen that career optimism has a fully mediating role between the role modeling and career adaptabilities. In addition, career optimism has a fully mediating role between role modeling and career self-efficacy.
\end{abstract}

Keywords: Mentoring Functions, Career Adaptabilities, Career Self-Efficacy, Career Optimism

\section{Introduction}

Since the rapid changings and continuous innovations in both technological and economical areas, universities are considered as main components, which play a crucial role in the education of human capital from the point of cultural, social, political and economic perspective. However, academic members, who were assigned for various fields, are seen as one of the vital aspects of universities, due to the play an important role for guidance and growth of society and young adults (Parsa et al., 2016: 295). These are examined as one of the pioneer and significant components for young adults to cope with the twenty-first century's conditions (Dibia and Obi, 2013: 121). While, the academic members have significant responsibilities in formal learning process for the students, it is expected that they play a part in mentoring, coaching, networking, and self-directed learning phases (Knippelmeyer and Torraco, 2007: 1). In other words, universities can support their students' social and vocational development, foster their sense of belonging and shape their futures through one way which is called mentoring (Liua and McGrath-Champ, 2014: 4). In universities, career and professional advancement of young adults are based on mutual recognition and fulfillment of needs, such as professional development, including mentoring which aims to provide challenging assignments, protect them from adverse forces, and help to possess a positive vision (Parsa et al., 2016: 295-296). As the students' success measured by a number of variables like graduation rate, course completion and retention, advising and mentoring are regarded key components of a successful university experience. Because mentoring refers to assisting of students to prepare them for a better career and providing them with social networks and helping them to increase their self-esteem and confidence levels. Essentially, mentoring process maintains a major role in supporting the students' success in many ways (Fedynich and Bain, 2011: 2-5). On the other 
hand, mentoring relations comprise teaching, assisting, and acting as a role model, providing time, energy and material support to facilitate inspiration of less experienced individuals (Anafarta and Apaydın, 2016: 22).

Due to the mentor can offer a young adult personal support, encouragement, friendship and give an advice for the future career and also share their life experiences, they are considered as the most influential person in students' life. In this context, it is possible to express that mentoring relations bring some positive outcomes such as getting higher degrees, increasing self-esteem and self-efficacy levels, having good communication skills, planning future career and career transitions (Foster and MacLeod, 2004: 442-443). In addition, it can be said that mentoring functions lead students' career competencies, career self-efficacy and career optimism levels increasing, and help them to gain success in career related activities such as career development and career adaptabilities. Therefore, mentoring functions are examined as significant factors that will shape the students' future careers more effectively and facilitate the planning and exploring activities. Accordingly, this study aims to investigate the effects of mentoring functions on students' career self-efficacy and career adaptability levels and the mediating role of career optimism. In the literature, it seen that researches related to mentoring were conducted at organizational fields, rather than education. Moreover, there is not any research existing in literature that examines the relationships among mentoring functions, career self-efficacy, career adaptabilities and career optimism on undergraduate students. Thus, this study aims to investigate the beneficial effects of mentoring functions on careerrelated components so it attempts to contribute to the literature.

\section{The Theoretical Framework and Research Hypotheses}

\subsection{Mentoring Functions}

Mentoring is considered as one of the most significant career management techniques which support individual's career developments in conjunction with other mechanisms. Among the other mechanisms, mentoring is recognized as the most effective technique that helps particularly young adults to discover their strengths and weakness and adapt to changing conditions and to facilitate the process of identifying their abilities (Alayoğlu, 2012: 135). Along with the career developing role of mentoring, it also reduces deviant behaviors, promotes self-identity and self-image, and increases academic achievement and school success. Due to its significant role in different areas such as education, community and business, there is a definitional and conceptual confusion on "what mentoring is". However, the study about the role of mentoring on adults' development is traced back to the Levinson and colleagues research. According to this research, mentor is described as a guide, teacher, counselor and developer of skills who "facilitates the realization of the dreams" and "the vision that one wants as an adult" (Eby et al., 2010: 7-8). Generally, mentoring is described "as the relationship between older or more experienced mentor and a less experienced protégé or young person who aims of helping and developing younger individuals' careers (Ragins and Kram, 2007: 5). Mentoring is also characterized as a relationship, where the experienced individual aims to serve as a role model, to provide support and direction to the younger protégé. In addition, mentoring purpose is to provide feedback to the protégés related with the career plans and individual development and to help them to gain success in both social and business life. According to Kram (1985) mentoring relationships provide two different categories of mentoring functions labeled as career related mentoring functions and psychosocial mentoring functions (Day and Allen, 2004: 2).

Career-related mentoring functions refer to help the protégés career advancement and foster the enhancement of their sense of competence. These relationships involve coaching, protection, sponsorship, visibility and provision. For example, mentor as coach's share their ideas, provide feedback and give suggestions to gain success. In addition, they have to eliminate risky conditions which might threat young adult's reputation and nominate lateral moves and promotions and also mentors have to provide challenging assignments which help increasing protégés' visibility (Park et al., 2016: 1176). On the other hand, psychological mentoring functions represent the interpersonal aspect of these relationships which includes role modeling, counseling, friendship and acceptance. In other words, mentors aim to increase protégés' sense of competence, identity, and effectiveness in their social and professional lives (Allen et al., 2004:128). Psychological mentoring functions intend to maintain closeness and trust in mutual relationships and include positive behaviors which lead to enhance the protégés self-esteem, self-efficacy and personal growth levels (Ragins and Kram, 2007: 5). Apart from the career-related and psychological mentoring functions, it is suggested by Scandura (1992) that there is a third category of mentoring function called role-modeling. Role modeling includes illustrative behaviors, who have high standards, welltrusted and respected in their work and social life that ensure to shape protégés future in a positive way (Arora and Rangnekar, 2014: 209). However, role-modeling mentoring functions based on the traditional mentoring due to its characteristics, such as mentors aims to represent exemplary behaviors, skills and attitudes towards to the protégés, by 
this way it is expected that young adults thoughts, attitudes and behaviors change favorably (Chen, 2013: 201). Therefore, it can be said that the main role of all mentoring functions is to increase the protégés effectiveness and to encourage and strengthen them. In general, mentoring functions intend to help improving performance and career development and to share knowledge, experiences, and opinions. In this framework, it is possible to express that mentor, who may also be referred to as coach, teacher, advisor, counselor, aims to indoctrinate inexperienced young individuals under their protection and also tend to prepare them for life and the future either voluntarily or by assignment of some duties (Alayoğlu, 2012: 138-139).

\subsection{Career Self-Efficacy, Career Optimism and Career Adaptabilities}

Career self-efficacy refers to the individuals' expectation and conviction to their abilities in relation to the wide range of behaviors involved in career choice, career development and adjustment. In general, there are two lines of inquiry under career self-efficacy; one of them represents having a successful career in a certain area and the other aims to investigate different occupational domains (Zeldin, 2000: 22). However, career self-efficacy is considered as the belief of individuals which leads them to avoidance of or motivates them toward career-related behaviors. It plays a crucial role in determining the behavior of young adults in different complicated situations when planning their careers. For example, high career selfefficacy in complex situations helps young adults to overcome feelings of doubt, anxiety and unpleasant events and facilitate solution of conflicts with much greater ease. Individuals with high career self-efficacy have high career ambitions which lead to set higher career goals and objectives (Kanten et al., 2016: 847). In addition, higher career self-efficacy reveals individuals self-confidence to the completion of career-related tasks efficiently, which leads to positive outcomes such as career success, career satisfaction and career exploration. On the other hand, individuals with low career self-efficacy cannot make effective career-related decisions and limit career options in their surroundings due to the lack of their abilities (Makki et al., 2015: 428). Therefore, it is possible to express that career self-efficacy is considered as an important component that ensures young adults to make the right choices related to their careers, facilitates their adaptation to the changing, complicated and dynamic conditions and leads to increasing of their willingness to participate in career related activities.

Due to the today's turbulent career landscape, it is seen that career self-management comes more important than ever before. In other words, technological advancements, job restructuring, and an increasingly globalized workforce careers have become less structured and predictable and required individuals to be flexible and adaptable. However, individuals needed to have some career competencies such as technical and conceptual skills which are essential for successful performance of one's chosen career. These competencies are considered as transferable and non-intellective capabilities like self-efficacy, conscientiousness, resilience and optimism which foster individuals to persevere against uncertainty and complexity (Garcia et al., 2015: 10). Career optimism characterized as the tendency for individuals to expect the best possible outcomes or to emphasize the most positive viewpoints of one's career in future. Career optimism refers to the generalized expectations that good things will happen related to one's career in the future. It is assumed that these expectations may affect goal-setting behaviors of individuals such as those lead to achieve career outcomes. In addition, it is asserted that career optimism has potential benefits making right career choices and establishing favorable career plans (Rottinghaus et al., 2005: 5-11). For example, it is expected that optimistic individuals more likely to make efforts to accomplish their career goals than pessimistic ones. In particular, students who have career optimism tend to meet with a counselors, advisors or mentors to receive a help related to their career goals and plans. Moreover, optimistic individuals try to use alternative ways and methods to gain success, can easily change their career plans and goals or modify their career-related behaviors according to changing conditions (Rottinghaus, 2004: 23-24). In this context, it can be inferred that career optimism provides individuals to have positive emotions, hope, resilience, and self-efficacy which facilitate to get success in career-related activities.

Nowadays, it is seen that individuals' career patterns are becoming more boundaryless and non-linear, which requires selfregulatory resources solving problems and improving person-environment fit during the career development process (Cai et al., 2015: 85). Career adaptabilities are considered as one of the resources that are placed in the hearth of young adults' career development and are defined as the abilities to adjust individuals to fit in new and changed situations while career planning or making decisions about the future (Barto et al., 2015: 55). Career adaptabilities are characterized as a "psychological construct that represents individual resources for coping with the existing and anticipated tasks, transitions and traumas in the occupational roles. In other words, it composes of self-regulatory, transactional and malleable competencies that provide individuals to solve unknown, complex, multi-dimensional and ill-defined problems along with 
their careers (Rudolph et al., 2017: 17). However, it refers to the attitudes, beliefs and competencies examined as four dimensions such as concern, control, confidence and curiosity. While concern indicates a tendency to participate in careerrelated activities and future time orientation, control represents self-discipline and willingness and to take responsibility with one's career. In addition, curiosity shows the individuals' openness to the new experiences and dispositions to the self and environmental explorations related with career opportunities, whereas confidence refers to the belief of individuals to cope with the challenges in career development process. In the literature, it is seen studies suggested that career adaptabilities dimensions are significantly related to the variety of vocational outcomes (Taber and Blankemeyer, 2015: 21). For example Zacher $(2014 ; 2015)$ asserted that career adaptability and its dimensions positively related with crucial outcomes such as job and career satisfaction, job search success, job and self-reported career performance, graduates employment quality and job seeker's re-employment quality. However, Karavdic and Baumann (2014) indicated that career adaptabilities positively related with individual's life satisfaction, hope and happiness.

According to the current studies, it can be inferred that career adaptabilities lead individuals to be more capable of seeking job opportunities and finding jobs, ensure them to be successful in transitional period between school to work or career life span, securing high quality employment. In addition, these adaptabilities make adjustment to the new working conditions, career-related changings, and person-environment integration easier (Tolentino et al., 2014: 40). Therefore, it is possible to express that career adaptability is considered as a main component of successful career preparation through helping young adults to formulate their career plans and career goals related to the individual characteristics and preferences. Because, rapidly changing global conditions and life-span career approaches need individuals to have career adaptabilities which facilitate them to meet requirement of career development process and employment demands (Tuna et al., 2014: 143) By the reason of career transitions and new career approaches such as boundaryless career, protean career, dual ladder career path, flexible career, dual career and etc. young adults need to have some skills which foster them to adapt to the new career development process, new work roles, and quick job transitions. Thus, career adaptabilities regarded as a key component throughout a young adults' career choices, career exploration and career-related behaviors in today's working conditions. Due to its importance, it is seen that researchers focus on individual, environmental or contextual predictors which may trigger career adaptability levels of young adults.

\section{Research Hypotheses}

Mentoring in undergraduate and graduate education field is considered as a key element of young adults' vocational and professional development process. In other words, as faculty and vocational school members are regarded as an essential mechanism for indoctrinating students into the vocational and professional field, and they serve as role models which provide students a realistic view about their chosen profession. Moreover, it is expected that mentoring relationship may have profound effects on students' professional identity, career plans and career success (Eby et al., 2010: 16). Since mentoring is recognized as an important and a powerful tool of career management as it has some advantages such as development of students' skills, facilitate their access to reach organizational resources, increasing of career satisfaction and clarifying of goals for the young adults. In the literature, it is seen many empirical studies suggest that mentoring relationships result in some positive career outcomes such as more promotions, more mobility, higher income, career satisfaction, career commitment (Allen et al., 2006: 277; Seema and Sujatha, 2015: 35). For example, Schunk and Mullen (2013) indicated that mentoring behaviors including coaching, counseling, providing feedback or role-modeling can lead to positive protégé outcomes like learning, goal setting, career development and can also induce some favorable psychological outcomes such as motivation, satisfaction, and sense of identity. In addition, Jyoti and Sharma (2017) found that mentoring relationships have positive effects on individual's self-efficacy and personal learning levels, relationship quality, communication satisfaction and job performance. From the positive career outcomes perspective, Day and Allen (2003) suggested that mentoring relationships increase individuals' career self-efficacy and career motivation levels. Anafarta and Apaydın (2016) emphasized that mentoring relationships have an impact on faculty members' career satisfaction and career success levels. However, Jyoti and Sharma (2015) suggested that mentoring functions positively influence career development process of individuals which involves assessing the current position and taking steps to reach the future position. On the other hand, Parsa et al., (2016) found that mentoring relationships also have positive impacts on individual's career advancement levels and Scott (2010) revealed that mentoring functions have significant effects on career exploration. In consideration of these research results, it can be inferred that mentoring functions have profound effects on favorable career outcomes of young adults such as career success, career satisfaction, career motivation, career advancement, career exploration, career development, career self-efficacy. Therefore, it is expected that one of the 
dimensions of mentoring functions which is labeled as role-modeling has influence on students' career adaptability; career self-efficacy and career optimism levels and the following hypotheses are proposed:

$\mathrm{H}_{1}$ : Role modeling mentoring significantly influences career adaptability levels of students.

$\mathrm{H}_{2}$ : Role modeling mentoring significantly influences career self-efficacy levels of students.

$\mathrm{H}_{3}$ : Role modeling mentoring significantly influences career optimism levels of students.

Due to the importance of personal characteristics and career adaptabilities in individuals' career development, it is seen that researchers focus on the antecedents of this concept. For example, it has been found that both self-esteem and proactive personality are considered as significant precursors of individuals' career adaptability levels (Cai et al., 2015: 87). However, van Vianen et al., (2012) and Rossier et al., (2012) asserted that big five personality traits have significant effects on individual's career adaptabilities. In addition, it is indicated that career optimism positively related to individual's career adaptabilities. Career optimism provides individuals to overcome career obstacles, to perform career plans effectively and helps them to enhance their career insight. Moreover, individuals who have career optimism tend to manage changing and uncertain conditions favorable because they are flexible, stable and ready for using adaptive coping strategies. Based on these reasons, it is expected that career optimism positively related to career self-efficacy and career adaptability levels of individuals (Tolentino et al., 2014: 42). Bandura's social cognitive career theory (SCCT) suggests that individuals' selfefficacy beliefs may influence their career choices, performance and success in career related activities and behaviors. As career self-efficacy resources help individuals to adjust themselves to the changing conditions and foster them to respond quickly to the career development situations (Ebenehi et al., 2016: 217). In other words, it can be inferred that career optimism and career self-efficacy also has positive relations with favorable career attitudes, career exploration and career decidedness, so it is examined as a significant motivational factor that influence various career behaviors (Creed et al., 2007: 378). Therefore, it is expected that career optimism has influence on students' career self-efficacy and career adaptability levels and it has a mediator role, so the following hypotheses are proposed:

$\mathrm{H}_{4}$ : Career optimism significantly influences career self-efficacy levels of students.

$\mathrm{H}_{5}$ : Career optimism significantly influences career adaptability levels of students.

$\mathrm{H}_{6}$ : Career optimism has a mediating role on the relationship between role modeling mentoring and career self-efficacy levels of students.

$\mathrm{H}_{7}$ : Career optimism has a mediating role on the relationship between role modeling mentoring and career adaptability levels of students.

In literature, it is seen that besides the personal antecedents, researchers try to reveal out the environmental or contextual precursors of career adaptabilities. For example Creed et al., (2009) and Yousefi et al., (2011) indicated that social support, which refers to the family and friends have significant effect on career adaptability levels of individuals. However, Kanten (2012) asserted that career adaptability levels of student's differ based on their gender, willingness to choice of graduate program and the planning to work in the graduated field or not and the social environment. Coetzee and Harry (2015) suggested that gender and hardiness are significant predictors of career adaptabilities. In addition, Kadir and Deniz (2016) found out career adaptability levels of student's differ based on whether young adults made their departmental choice consciously and they have previous education or training. In this context, it is expected that according to the some demographical variables student's career self-efficacy, career optimism and career adaptability levels may differ or not. Thus, the following hypotheses are proposed

$\mathrm{H}_{8}$ : Career optimism levels of students differ depending on their gender.

$\mathrm{H}_{9}$ : Career adaptability levels of students differ depending on their gender.

$\mathrm{H}_{10}$ : Career adaptability levels of students differ depending on whether they have planning to work in the graduated field or not.

$\mathrm{H}_{11}$ : Career self-efficacy levels of students differ depending on their social environment.

Figure 1. Research Model 


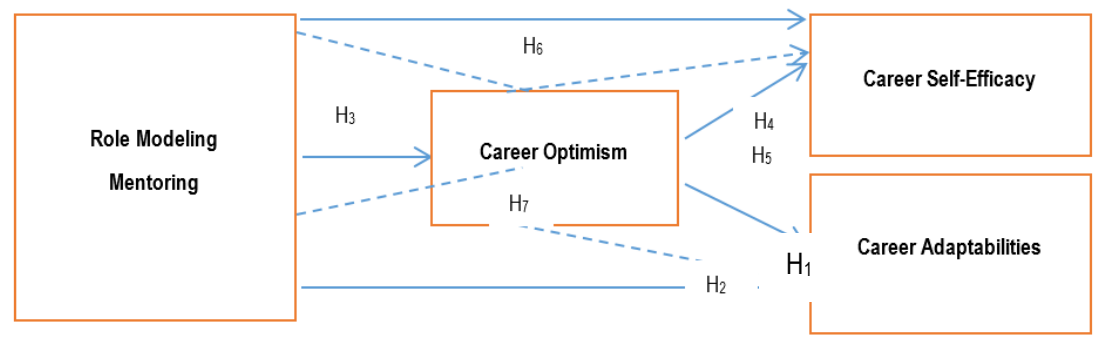

\section{Research Method}

\subsection{Sample and Procedures}

The sample of the research was composed of two faculties and two high schools from the University of Canakkale Onsekiz Mart in Turkey. The participants of the study consist of 311 students who have being education as a second class and above students that were determined via convenient sampling method. From the 500 questionnaires that have been sent out, 360 have been returned, representing a response rate of $72 \%$. After elimination of cases having incomplete data and outliers 311 questionnaire (62\%) have been accepted as valid and included in the evaluations. However, questionnaire survey method is used for data collection in this study. Questionnaire form contains four different measures related to research variables.

\subsection{Measures}

Measures used in the questionnaire forms have been adapted from the previous studies in the literature. All measures have been adapted to Turkish by the lecturers and pilot study has been conducted for the validity of these measures. Before the distribution of the survey to the actual sample, a pilot study was conducted in order to determine whether the questions had been understood properly and to check the reliability of the scales. As a result of the pilot study, some corrections have been conducted in the questionnaire forms. A Likert-type metric, that is, expressions with five intervals has been used for answers to the statements of survey. Anchored such; "1- strongly disagree, 2- disagree, 3- agree or not agree, 4- agree, 5strongly agree". However, 8 demographic questions were asked in the questionnaire form. Firstly, all scales were subjected to the exploratory factor analyses to check the dimensions, and then confirmatory factor analyses were applied to all scales.

\section{Mentoring Functions Scale}

Students' perception of mentoring functions from their mentors measured with 15 items which was taken from Park et al., (2016) studies. Exploratory factor analysis using principal component analysis with varimax rotation was applied to the adapted scale to check the dimensions. As a result of the exploratory factor analysis data related to the mentoring functions variables, one item were removed from the analysis due to the factor loadings under 0.50 and three factor solutions; (career support, psychological support and role modeling) were obtained per theoretical structure. Factor loadings of the items ranged from .54 to .86 .

\section{Career Optimism}

Students career optimism attitudes measured with 9 items which was taken from Rottinghaus (2004) study. Exploratory factor analysis using principal component analysis with varimax rotation was applied to the adapted scale to check the dimensions. As a result of the varimax rotation of the data related to the career optimism variables, three items were removed from the analysis due to the factor loadings under 0.50 and one factor solution was obtained per theoretical structure. Factor loadings of the items ranged from .60 to .80 .

\section{Career Self-Efficacy Scale}

Students career self-efficacy levels were measured with 11 items which was taken from Kossek et al., (1998) studies. As a result of the exploratory factor analysis of the data related to the career self-efficacy variables, five items were removed from the analysis due to the factor loadings under 0.50 and one factor solution obtained per theoretical structure. Factor loadings of the item ranged from 66 to .85 . 


\section{Career Adaptabilities Scale}

Students career adaptabilities levels were measured with 24 items which was taken from Kanten (2012) study. As a result of the exploratory factor analysis of the data related to the career adaptabilities variables, six items were removed from the analysis due to the factor loadings under 0.50 and four factor solution; (concern, control, curiosity and confidence) were obtained per theoretical structure. Factor loadings of the item ranged from .57 to .84 .

Table 1: Results of Exploratory and Reliability Analyses

\begin{tabular}{|c|c|c|c|c|c|c|c|}
\hline $\begin{array}{l}\text { Career } \\
\text { Adaptabilities } \\
\text { (18 items) } \\
\text { KMO: } .900 \\
\text { Variance: } 67 \%\end{array}$ & $\begin{array}{l}\text { Cron. } \\
\text { Alpha }\end{array}$ & $\begin{array}{l}\text { Mentoring Functions } \\
\text { (14 items) } \\
\text { KMO: } .932 \\
\text { Variance: } 73 \%\end{array}$ & $\begin{array}{l}\text { Cron. } \\
\text { Alpha }\end{array}$ & $\begin{array}{l}\text { Career } \\
\text { Optimism } \\
\text { (6 items) } \\
\text { KMO: .795 } \\
\text { Variance: } \\
53 \%\end{array}$ & $\begin{array}{l}\text { Cron. } \\
\text { Alpha }\end{array}$ & $\begin{array}{l}\text { Career Self- } \\
\text { Efficacy } \\
\text { (6 items) } \\
\text { KMO: } .858 \\
\text { Variance: } 59 \%\end{array}$ & $\begin{array}{l}\text { Cron. } \\
\text { Alpha }\end{array}$ \\
\hline 1. Factor: Concern & .779 & $\begin{array}{l}\text { 1. Factor: Career } \\
\text { Support }\end{array}$ & .934 & $\begin{array}{l}\text { 1. Factor: } \\
\text { Career } \\
\text { Optimism }\end{array}$ & .821 & $\begin{array}{l}\text { 1. Factor: } \\
\text { Career Self- } \\
\text { Efficacy }\end{array}$ & .863 \\
\hline 2.Factor: Control & .863 & $\begin{array}{l}\text { 2.Factor: } \\
\text { Psychological Support }\end{array}$ & .871 & & & & \\
\hline $\begin{array}{l}\text { 3.Factor: } \\
\text { Curiosity }\end{array}$ & .773 & $\begin{array}{l}\text { 3.Factor: Role } \\
\text { Modelling }\end{array}$ & .837 & & & & \\
\hline $\begin{array}{l}\text { 4.Factor: } \\
\text { Confidence }\end{array}$ & .879 & & & & & & \\
\hline
\end{tabular}

After the exploratory factor analysis, the confirmatory factor analysis have been conducted by Lisrel 8.8 for all scales. Goodness of fit indexes is presented in Table 2. It can be seen that all of the fit indexes fall within the acceptable ranges (Schermelleh-Engel et al., 2003: 52; Meydan and Şeşen, 2011: 35).

\section{Table 2. Goodness of fit indexes of the scales}

D Variables $\chi^{2}$ df. $\chi^{2} / \mathrm{df}$ GFI AGFI CFI NFI NNFI RMSEA

$\leq 5 \geq .85 \geq .80 \geq .90 \geq .90 \geq .90 \leq 0.08$

Mentoring Functions 191.84722 .660 .930 .890 .990 .980 .980 .070

Career Adaptabilities 256.06962 .660 .910 .880 .980 .960 .970 .070

Career Self-Efficacy 15.1081 .880 .990 .960 .990 .990 .990 .051

Career Optimism 0.7810 .781 .000 .991 .001 .001 .000 .000

\subsection{Data Analysis}

SPSS for Windows 20.0 and Lisrel 8.80 programs were used to analyze the obtained data. After the exploratory and confirmatory analyses, descriptive statistics such as means, standard deviations and pearson correlation analysis of the study variables were examined. Following that, structural equation modelling (SEM) was used to conduct a test of the hypotheses in the research model.

\section{Research Findings}

\subsection{Respondent Profile}

$55 \%$ of the students were female and the $45 \%$ of them male. Majority of the students $(68 \%)$ were between the ages $18-21$, $32 \%$ of them between the ages $22-25.32 \%$ of the students have an education in business administration, $30 \%$ of them in international trade and logistics, $28 \%$ of them in labour economics and industrial relations, $10 \%$ of them in public management bachelor's degree programs. However, majority of the students $(80 \%)$ indicated that they are third and fourth grade students. In addition, majority of the students (81\%) indicated that they have chosen their education programmes willingly and most of the students (82\%) are planning to work in the field that they have graduated. 


\subsection{Descriptive Analyses}

In the scope of the descriptive analyses means, standard deviations and correlations have been conducted which are related to mentoring functions, career adaptabilities, career optimism and career self-efficacy levels of student. The values are given in Table 3.

Table 3. Means, standard deviations and correlations of the study variables

\begin{tabular}{|l|l|l|l|l|l|l|l|l|}
\hline & Mean & S.S & 1 & 2 & 3 & 4 & 5 & 6 \\
\hline Career Support & 3.23 & .91 & 1 & & & & & \\
\hline Psychological Support & 3.01 & .92 & $.716^{* *}$ & 1 & & & & \\
\hline Role Modeling & 3.38 & .91 & $.661^{* *}$ & $.595^{* *}$ & 1 & & & \\
\hline Career Optimism & 3.96 & .78 & $.220^{* *}$ & $.183^{* *}$ & $.354^{* *}$ & 1 & & \\
\hline Career Self-Efficacy & 3.47 & .89 & .018 & -.028 & .090 & $.326^{* \star}$ & 1 & \\
\hline Career Adaptabilities & 4.03 & .56 & $.162^{* *}$ & $.127^{*}$ & $.294^{* *}$ & $.590^{* *}$ & $.413^{\star *}$ & 1 \\
\hline
\end{tabular}

${ }^{* *} p<0.01 ;{ }^{*} p<0.05$

As can be seen in Table 3, mentoring functions dimension of career support ( $r=.162, p<0.01)$; psychological support ( $r=.127$, $p<0.05)$ and role modeling $(r=.294, p<0.01)$ were positively related to students career adaptability levels. Mentoring functions all dimensions such as career support $(r=.220, p<0.01)$; psychological support $(r=.183, p<0.01)$ and role modeling $(r=.354, p<0.01)$ were positively related to students career optimism levels. However, mentoring functions dimensions were not related with career self-efficacy levels of students. In addition career optimism was positively related with ( $r=.326$, $p<0.01)$ career self-efficacy and career adaptabilities $(r=.590, p<0.01)$. Therefore, it is possible to express that mentoring functions dimension labeled as role modeling was more related with career adaptability levels of students than the others.

\subsection{Measurement Model}

For the verification of the model two step approach by Anderson and Gerbing (1988) has been used. According to this approach, prior to testing the hypothesized structural model, first the research model needs to be tested to reach a sufficient goodness of fit indexes. After obtaining acceptable indexes it can be proceed with structural model. As a result of the measurement model, 6 latent and 36 observed variables were found. Observed variables were consist of 14 items related to mentoring functions, 13 items related to career adaptabilities; 5 items related to career self-efficacy and 4 items related to career optimism. The results of the measurement model were; $x^{2}: 1090.60 ; \mathrm{df}: 570 ; x^{2} / \mathrm{df} ; 1.91$; RMSEA: $0.052 ; \mathrm{GFI}$ : 0.85; IFI: 0.97; CFI: 0.97 ; NFI: 0.95 ; NNFI: 0.97 . These values indicate that measurement model has been acceptable (Schermelleh-Engel et al., 2003: 52; Meydan and Şeşen, 2011: 37).

\subsection{Structural Equation Model}

After the measurement model was demonstrated as acceptable, the structural equation model was applied to verify hypotheses for the causal relationships in the research model. The results of the structural equation model were; $x^{2}: 538.24$; df: 200; $x^{2} / d f: 2.69 ;$ RMSEA: 0.071; GFI: 0.87; CFI: 0.95; IFI: 0.95; NFI: 0.93; NNFI: 0.95. These results indicate that structural model has been acceptable (Schermelleh-Engel et al., 2003: 52; Meydan and Şeşen, 2011: 37).

Figure 2. Structural model and path coefficients related with direct effects

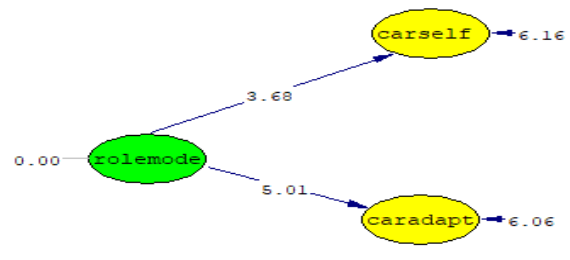


Chi-Square $=538.24, \mathrm{df}=200, \mathrm{P}-\mathrm{value}=0.00000, \mathrm{RMSEA}=0.071$

According to the results of structural equation model, the path parameter and significance levels show that role modeling has positive and significant effects on students career-self efficacy ( $\gamma=0.24$; t-value $=3.68)$, and career adaptability $(\gamma=0.34$; $\mathrm{t}$-value $=5.01$ ) levels, so $\mathrm{H}_{1}$, and $\mathrm{H}_{2}$ hypotheses were supported. These results indicated that role modeling mentoring function which includes representing illustrative attitudes and behaviors or serve as role modeling may increase students' career self-efficacy and career adaptability levels. Because of the mentors who aim to be a role model by sharing their knowledge, experiences and thoughts with protégé, increase young adult self-confidence levels and enhance their beliefs that they perform tasks successfully. On the other hand, based on the role modeling mentoring functions, it is expected that young adults may adapt themselves changing and unclear situation easily. Thus, it can be inferred that role modeling mentoring facilitates students to search for several career opportunities, to have an interest and willingness to participate in career-related activities and have a desire to plan their future career.

Our study additionally used the testing approach of Baron and Kenny (1986) to examine whether career optimism mediating variable or not. According to this approach, following conditions were used for the mediation analysis (Baron and Kenny, 1986); there is a significant relationship between the independent variable and the dependent variables (role modelingcareer self-efficacy); (role modeling and career adaptabilities); there is a significant relationship between the independent variable and the mediator variable (role modeling and career optimism) and there is a significant relationship between the dependent variables and the mediator variable (career optimism-career self-efficacy); (career optimism-career adaptabilities). After the research model tested in accordance with the Baron and Kenny (1986) approach, the results of the structural equation model were; $x^{2}: 675.64 ;$ df: 286; $x^{2}$ /df: 2.36; RMSEA: 0.063; GFI: 0.87; CFI: 0.96; IFI: 0.96; NFI: 0.94; NNFI: 0.96. These results indicate that structural model has been acceptable (Schermelleh-Engel et al., 2003: 52; Meydan and Şeşen, 2011: 37).

\section{Figure 3. Structural model and path coefficients related with mediator effect}

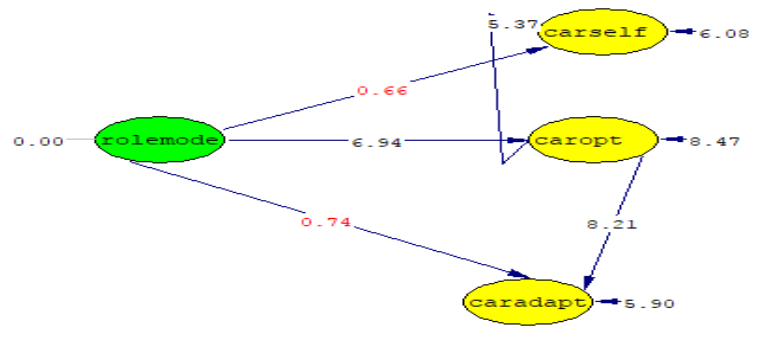

According to the Baron and Kenny (1986) approach, results of structural equation model in figure 3 shows that the role modeling has positive and significant effects on students career optimism levels $(\gamma=0.45$; t-value $=6.94)$ and also students' career optimism levels $(\gamma=0.63$; $t$-value $=8.21)$ have positively and significantly affect their career adaptability levels, thus $\mathrm{H}_{3}$ and $\mathrm{H}_{5}$ hypotheses were supported. In addition, career optimism has positive and significant effect on students' career self-efficacy levels ( $\gamma=0.39$; t-value $=5.37$ ) and $\mathrm{H}_{4}$ hypothesis was supported. Moreover, considering the mediator role of career optimism, it has been observed that, the effects of role modeling on students career self-efficacy levels was not continued $(\gamma=0.04$; t-value $=0.66)$, so it is possible to express that career optimism has a fully mediator role the on relationship between role modeling mentoring function and career self-efficacy levels of students, $\mathrm{so}_{6} \mathrm{H}_{6}$ hypothesis was supported. On the other hand, it has been observed that the effects of role modeling on career adaptabilities was not continued $(\gamma=0.04$; $t$-value $=0.74)$, so it is possible to express that career optimism has a fully mediator role the on relationship between role modeling mentoring function and career adaptability levels of students, $\mathrm{so}_{7}$ hypothesis was supported. In other words, while figure 2 shows the direct effects of research model, figure 3 shows the changing of path 
coefficients after the mediator variable addition. Therefore, by the comparing of path coefficients both figures, it is possible to recognize the mediating effects. In this context, it can be said that role modeling mentoring function may increases student's career self-efficacy and career adaptability levels in case they have career optimism. As a result, even young adults' perceive role modeling support from their mentors, career self-efficacy and career adaptability levels increase or decrease based on their career optimism levels.

\subsection{Independent Samples T-Test}

Independent samples t-tests were applied to determine student's career optimism and career adaptabilities levels differ according to their gender and whether they are planning to work in the field that they have graduated or not.

Table 4. Independent Samples T Test for Gender

\begin{tabular}{|l|l|l|l|l|}
\hline & Gender & Mean & t & Sig. \\
\hline Career Optimism & Female & 3.95 & \multirow{2}{*}{-.393} & \multirow{2}{*}{. $\mathbf{0 3 4}^{*}$} \\
\cline { 2 - 5 } & Male & 3.98 & & \multirow{2}{*}{-.831} \\
\hline Career Adaptabilities & Female & 4.06 & $.024^{*}$ \\
\cline { 2 - 3 } & Male & 4.01 & -831 \\
\hline
\end{tabular}

${ }^{* *} \mathrm{p}<0.05$

Table 4. Independent Samples T Test for Planning to Work Graduated Field

\begin{tabular}{|l|l|l|l|l|}
\hline & Planning to Work Graduated Field & Mean & $\mathbf{t}$ & Sig. \\
\hline \multirow{2}{*}{ Career Adaptabilities } & Yes & 4.09 & \multirow{2}{*}{3.590} & \multirow{2}{*}{$.028^{*}$} \\
\cline { 2 - 3 } & No & 3.80 & \\
\hline
\end{tabular}

${ }^{* *} \mathrm{p}<0.05$

According to the results of the independent samples t test, the significance levels show that students' career optimism and career adaptability levels differ related with their gender so $\mathrm{H}_{8}$ and $\mathrm{H}_{9}$ hypotheses were supported. However, it has been observed that while female student's career adaptability levels more high than male students; males' career optimism levels higher than females. Therefore, it can be inferred that boys have much more positive feelings related to their future career than girls. On the other hand, girls' curiosity and concern levels related to their future career higher than boys so their career adaptation levels higher than the boys. In addition, research results revealed that student's career adaptation levels differ whether the education program related the area that they are planning to work in the future or not. Thus, $\mathrm{H}_{10}$ hypothesis was supported. In this context, it can be expected that students, who are planning to work in graduated field in the future, have higher career adaptability levels than others. These results indicate that students tend to research the business field and like to participate in various career activities such as seminars, workshops and conferences which are related to their education program.

\subsection{One-Way Anova Results}

One-way anova test was applied to determine student's career self-efficacy levels differ according to their social environment that they have grown up or not.

Table 5. One-way Anova Test for Social Environment

\begin{tabular}{|c|c|c|c|c|c|c|c|}
\hline \multirow[t]{3}{*}{$\begin{array}{l}\text { Career } \\
\text { Efficacy }\end{array}$} & \multirow[t]{3}{*}{ Self- } & Social Environment (I) & Social Environment (J) & $\begin{array}{l}\text { l-J (Differences } \\
\text { between the } \\
\text { means) }\end{array}$ & \multicolumn{2}{|c|}{$\begin{array}{l}\text { Means of Career } \\
\text { Self-Efficacy }\end{array}$} & Sig. \\
\hline & & City & Village & .46894 & $\begin{array}{l}\text { City } \\
\text { Village }\end{array}$ & $\begin{array}{l}3.532 \\
3.062\end{array}$ & $.023^{*}$ \\
\hline & & Town & Village & .58603 & $\begin{array}{l}\text { Town } \\
\text { Village }\end{array}$ & $\begin{array}{l}3.648 \\
3.062\end{array}$ & $.007^{* *}$ \\
\hline
\end{tabular}

${ }^{*} p<0.05^{* *} p<0.001$

According to the results of the one-way anova test, the significance levels show that students' career self-efficacy levels differ related to their social environment such as city, town or village that they have grown up in, so $\mathrm{H}_{11}$ hypothesis was 
supported. It can be observed that the career self-efficacy level means of the students, who stated that they have grown up in a city, were different from the ones, who have grown up in a village. In addition, it is seen that students career selfefficacy level means differ according to whether they have grown up in a town or village. In this context, it can be inferred that the places where the individuals were born and grew up may affect their self-confidence levels and beliefs of their ability to perform given tasks effectively.

\section{Conclusion and Implications}

In the twenty-first century conditions universities represent the main environmental component which plays a significant role in the education of individuals from the several aspects. Generally, it is accepted that besides the formal learning process, universities have some socially beneficial responsibilities such as guiding young adults and making a contribution to their individual development. Accordingly, faculty or school members are expected to play a crucial role in guiding and developing process of young adults. In this context, mentoring relationships or functions are regarded as one of the key component of young adults' growth. Because effective mentoring relationships play vital part in university education due to its considerable effects on students' career choices, career plans, and career-related behaviors. However, based on the mentoring relationships including sharing of knowledge, experience, networking support, encouraging of courses or other issues, it is supposed that students' self-esteem, self-confidence, self-efficacy, motivation and academic success levels may increase. Therefore, mentoring functions lead students to acquire some skills, abilities and competencies which facilitate them to choice appropriate career, to seek out career opportunities and their adaptation to the changing conditions. In other words, mentoring functions which aim to develop young adults both educational and social perspectives are seen as the significant contributors for their career development process. In literature, it is seen that researchers focus on various effects of mentoring functions in organizational area. For example, these studies suggested that mentoring functions lead to increasing of individuals' job performance, motivation, job and career satisfaction, well-being, career commitment and etc. On the other hand, there are limited researches on an educational area which emphasized that effective mentoring functions lead to some positive career-related outcomes such as increasing of career motivation, career advancement, career self-efficacy, career exploration and career satisfaction. In consideration with these results, it is possible to express that mentoring functions triggers young adults' career-related attitudes and behaviors such as career self-efficacy, career optimism and career adaptability. Accordingly, this study aims to investigate some career related consequences of undergraduate students who have mentors in their academic institutions.

As a result of the research findings, it has been obtained that mentoring functions are one of the dimension, which is labeled as role modeling, and it has a positive effect on young adults' career adaptability, career self-efficacy and career optimism levels so $\mathrm{H}_{1}, \mathrm{H}_{2}$ and $\mathrm{H}_{3}$ hypotheses were supported. These results show that role modeling mentoring functions can be considered as significant predictors of career related attitudes and behaviors of students within the scope of the university. In this context, it can be inferred that role modeling mentoring function fosters students setting career goals and career plans, lead them to recognize and seek out career opportunities, increase their self-confidence and provides them with possession of a positive viewpoint for their future career. Based on the findings, it is seen that career optimism has a positive effect on students' career self-efficacy and career adaptability levels, so $\mathrm{H}_{4}$ and ${ }_{\mathrm{H} 5}$ hypotheses were supported. According to this result, career optimism facilitates young adults' ability to cope with complicated and uncertain conditions and also cause an increase in their career-self efficacy and career adaptability levels. Because career optimism provides students to have a positive belief and thoughts that lead them to perform effectively and to adapt themselves quickly career related situations. Therefore, students' career self-efficacy and career adaptability levels, which represent their confidence, concern, curiosity, and decidedness related to their future careers, can be affected positively by the career optimism levels within the scope of this research. On the other hand, it has been obtained that career optimism has a fully mediator role on the relationships between role modeling and career self-efficacy so $\mathrm{H}_{6}$ hypothesis was supported. Besides, it has been found that career optimism has a fully mediator role on the relationships between role modeling and career adaptability so $\mathrm{H}_{7}$ hypothesis was supported. In consideration with these results, it is expected that although students perceive a role modeling from their mentors, they have to possess positive feelings at the same time related to their future careers and their confidence and persuasion on their effective performance would increase. However, it is expected that students' career adaptability levels may increase if they perceive role modeling and have positive feelings related to their careers simultaneously. Apart from these, research results indicate that students' career optimism and career adaptability levels vary by their genders, thus, $\mathrm{H}_{8}$ and $\mathrm{H}_{9}$ hypotheses were supported. These results reveal that while females' career adaptability levels were higher than males, males' career optimism levels were higher than females. Moreover, it is seen that students' career adaptability levels differ depending on whether they have planning to work in the graduated field or 
not so $\mathrm{H}_{10}$ hypothesis was supported. It is possible to express that students, who plan to work in their vocational field have more concern, curiosity and confidence related to their careers and they tend to participate career-related activities more. It is also observed that career self-efficacy levels of students differ depending on their social environment like whether they were born and grew up in a city, town or village, so $\mathrm{H}_{11}$ hypothesis was supported. Thus, it can be inferred that the place where the students were born and grew up may be a significant underlying factor that represent their confidence or belief related to obtaining career success.

\section{Implications}

This study set light to some implications of role modeling mentoring functions in one of the Universities in Turkey. According to the results of the study, by providing effective role modeling it is possible to develop students from both vocational and individual perspective. However, there is growing and significant question that "who will be a good mentor" and "who can take this responsibility voluntarily". In Turkey, it seen that role modeling mentoring functions is more effective than psychological and career-related mentoring. Due to our society's characteristics, role modeling mentoring functions are more important than others. Because mentors, who are considered as role models can maintain more positive, close, and friendly relationships and illustrative attitudes and behaviors through affecting students in a favorable way. In addition, based on the fact that faculty members do not have sufficient time or desire to be mentors, these relationships cannot continue effectively. In our education system, mentoring relationship is not considered as compulsory responsibility, it is a voluntary activity. Therefore, it can be recommended to universities to choose most appropriate academicians for implementing mentoring relationships effectively and voluntarily. Thus, it is thought that formal mentoring systems can be performed in our universities which are expected to be more effective on increasing students' career adaptability and career self-efficacy or willingness to participate in career-related activities. On the other hand, there is not any empirical research existing in the literature investigating the relationships between mentoring functions, career optimism, career self-efficacy and career adaptability together. Furthermore, it is observed that mentoring studies which examine its antecedents and consequences are scant in the universities. Therefore, this study aims to make several contributions to the theory by exploring the relationships among these variables and determining the career-related consequences of mentoring functions.

\section{Limitations and Future Studies}

This study had some limitations. First, data were gathered from only two faculties and two of the vocational schools in one of the Universities in Turkey. Therefore, the results of this study cannot be considered as representative of all universities in Turkey. Second, the results are based on the perception of only the students who had a vocational education in business administration, international trade, and logistics, labor economics, and industrial relations, public management bachelor's degree programs. For future studies, it is recommended that the research model may be tested on different samples that are enrolled in different vocational programs, such as medicine, engineering, education, chemistry, psychics, etc. On the other hand, the research model can be redesigned by adding some contextual variables, such as school environment, social support that represents family and friends and etc.

\section{References}

[1] Alayoğlu, N. (2012). Mentoring: an ancient method of training and career development. TODAĐE's Review of Public Administration, 6(2), 135-170.

[2] Allen, T. D., Eby, L. T., Poteet, M. L., \& Lentz, E. (2004). Career benefits associated with mentoring for proteges: a meta-analysis. Journal of Applied Psychology, 89(1), 127-136.

[3] Allen, T. D., Lentz, E., \& Day, R. (2006). Career success outcomes associated with mentoring others a comparison of mentors and nonmentors. Journal of Career Development, 32(3), 272-285.

[4] Anafarta, A., \& Apaydın, Ç. (2016). The effect of faculty mentoring on career success and career satisfaction. International Education Studies, 9(6), 22-31.

[5] Anderson, J.C. and Gerbing D.W., 1988. Structural equation modeling in practice: A review and recommended two-step approach. Psychological Bulletin. 103 (3), 411-423.

[6] Arora, R., \& Rangnekar, S. (2014). Workplace mentoring and career resilience: an empirical test. The Psychologist-Manager Journal, 17(3), 205-220. 
[7] Baron, R. M. and D. A. Kenny (1986) . The moderator-mediator variable distinction in social psychological research. Conceptual, strategic, and statistical considerations. Journal of Personality and Social Psychology, 51(6), 1173-1182.

[8] Barto, H., Lambert, S., \& Brott, P. (2015). Career adaptability, resiliency and perceived obstacles to career development of adolescent mothers. The Professional Counselor, 5(1), 53-66.

[9] Cai, Z., Guan, Y., Li, H., Shi, W., Guo, K., Liu, K., Li, Q., Han, X., Jiang, P., Fang, Z., \& Hua, H. (2015). Selfesteem and proactive personality as predictors of future work self and career adaptability: an examination of mediating and moderating processes. Journal of Vocational Behavior, 86, 86-94.

[10] Chen, Y. (2013). Effect of reverse mentoring on traditional mentoring functions. Leadership and Management in Engineering, 13, 199-208.

[11] Coetzee,M., \& Harry, N. (2015). Gender and hardiness as predictors of career adaptability: an exploratory study among black call centre agents. South African Journal of Psychology, 45(1), 81-92.

[12] Creed, P. A., Fallon, T., \& Hood, M. (2009). The relationship between career adaptability, person and situation variables, and career concerns in young adults. Journal of Vocational Behavior, 74, 219-229.

[13] Ebenehi, A. S., Rashid, A. M., \& Bakar, A. R. (2016). Predictors of career adaptability skill among higher education students in Nigeria. International Journal for Research in Vocational Education and Training (IJRVET), 3(3), 212-229.

[14] Eby, L.T., Rhodes, J.E. \& Allen, T. D. (2010). "Definition and Evolution of Mentoring", Inside The Blackwell Handbook of Mentoring: A Multiple Perspectives Approach, Eds. T.D. Allen \& L.T. Eby. UK: Blackwell Publishing, 7-21.

[15] Fedynich, L., \& Bain, S. F. (2011). Mentoring the successful graduate student of tomorrow. Research in Higher Education Journal, 12, 1-7.

[16] Foster, S., \& MacLeod, J. (2004). The role of mentoring relationships in the career development of successful deaf persons. Journal of Deaf Studies and Deaf Education, 9(4), 442-458.

[17] Day, R., \& Allen, T. D. (2004). The relationship between career motivation and self-efficacy with protege career success. Journal of Vocational Behavior, 64(1), 72-91.

[18] Dibia, N.G. \& Obi, O.P. (2013). Academic advising and counselling in universities in south east Nigeria: a new perspective. Academic Journal of Interdisciplinary Studies. 2(10), 121-129.

[19] Garcia, P. R. J. M., Restubog, S. L. D., Bordia, P., Bordia, S., Roxas, R. E. O. (2015). Career optimism: The roles of contextual support and career decision-making self-efficacy. Journal of Vocational Behavior, 88, 10-18.

[20] Jyoti, J., \& Sharma, P. (2015). Impact of mentoring functions on career development: moderating role of mentoring culture and mentoring structure. Global Business Review, 16(4), 700-718.

[21] Jyoti, J., \& Sharma, P. (2017). Empirical investigation of a moderating and mediating variable in between mentoring and job performance: a structural model. Journal of Work and Organizational Psychology, 33, 55-67.

[22] Kadir, Y., \& Deniz, D. (2016). An analysis of young adults' career adapt-abilities from the perspective of various socio-demographic variables. Scientific Journal of Education, Sports, and Health, 2(XVII), 191-206.

[23] Kanten, S. (2012). Kariyer uyum yetenekleri ölçeği: Geçerlilik ve güvenilirlik çalışması. Süleyman Demirel Üniversitesi Sosyal Bilimler Enstitüsü Dergisi. 2(16), 191-205.

[24] Kanten, S., Kanten, P. \& Yeşiltaş, M. (2016). The Role of Career Self-Efficacy on The Effect of Parental Career Behaviors on Career Exploration: A Study on School of Tourism And Hotel Management' Students, 10th International Congress on Social Sciences, Madrid, 23 -24 September 2016, 845-857.

[25] Karavdic, S., \& Baumann, M. (2014). Positive career attitudes effect on happiness and life satisfaction by master students and graduates. Open Journal of Social Sciences, 2, 15-23.

[26] Knippelmeyer, S.A. \& Torraco, R.J. (2007). Mentoring as a Developmental Tool for Higher Education, Academy of Human Resource Development Conference Proceedings. University of Nebraska - Lincoln.

[27] Kossek, E.E., Roberts, K., Fisher, S. \& Demarr, B. (1998). Career Self-Management: A Quasi-Experimental Assesment of the Effects of a Training Intervention", Personnel Psychology, 51, 935-962.

[28] Kram, K. E. (1985). Mentoring at work: Developmental relationships in organizational life. Glenview, IL: Scott Foresman.

[29] Liua, H. \& McGrath-Champb, S. (2014). Inspired by Business': A case of mentoring among low socio-economic students, Research Paper, International Studies in Widening Participation, 1(1), 2-14. 
[30] Makki, B. I., Salleh, R., \& Harun, H. (2015). Work readiness, career self-efficacy and career exploration: a correlation analysis. International Symposium on Technology Management and Emerging Technologies (ISTMET), August 25-27, Langkawi, Kedah, Malaysia, 427-431.

[31] Meydan, C.H. \& Şeşen, H., 2011. Yapısal eşitlik modellemesi AMOS uygulamaları. Ankara: Detay Yayınclık.

[32] Park, J.H., Newman,A., Zhang, L., Wu, C., \& Hooke, A. (2016). Mentoring functions and turnover intention: the mediating role of perceived organizational support. The International Journal of Human Resource Management, 27(11), 1173-1191.

[33] Parsa, B., Parsa, P., \& Parsa, N. (2016). Mediation effect of self-efficacy on the relationship between mentoring function and career advancement among academics in Iran. Global Journal of Health Science, 8(10), 295-306.

[34] Ragins, B.R. \& Kram, K.E. (2007). "The Roots and the Meaning of Mentoring". Inside Handbook of Mentoring at Work: Theory, Research, and Practice. B.R. Eds. Ragins \& K.E. Kram. U.S.A: Sage Publications, 1-17.

[35] Rossier, J., Zecca, G., Stauffer, S.D., Maggiori, C. \& Dauwalder, J.P. (2012). Career adapt-abilities scale in a French-speaking Swiss sample: Psychometric properties and relationships to personality and work engagement. Journal of Vocational Behavior. 80(3), 734-743.

[36] Rottinghaus, P. J., Day, S. X., \& Borgen, F. H. (2004). The career futures inventory: a measure of career-related adaptability and optimism. Journal of Career Assessment, 13(1), 3-24.

[37] Rottinghaus, P. J. (2004). Assessing career optimism and adaptability: toward the construct validation of the career futures inventory. Unpublished doctoral dissertation, lowa State University, Ames, lowa.

[38] Rudolph, C.W., Lavignea, K.M. \& Zacherb, H. (2016). Career adaptability: A meta-analysis of relationships with measures of adaptivity, adapting responses, and adaptation results. Journal of Vocational Behavior, 98, 17-34.

[39] Scandura, T. A. (1992). Mentorship and career mobility: An empirical investigation. Journal of Organizational Behavior, 13, 169-174.

[40] Schermelleh-Engel, K., Moosbrugger H. and Müller, H. (2003). Evaluating the fit of structural equation models: tests of significance and descriptive goodness-of-fit measures. Methods of Psychological Research. 8 (2), 2374.

[41] Schunk, D.H. \& Mullen, C.A. (2013). "Self-Efficacy as an Engaged Learner", Inside Handbook of research on student engagement. Eds. S.L. Christenson, A.L. Reschly \& C.Wylie. New York: Springer, 219-235.

[42] Scott, J. A. (2010). The influence of role models, self-efficacy, carreer exploration, mentorship, educational aspirations, and academic enrichment on career aspirations of youth of youth in a precollege enrichmant program. Unpublished doctoral dissertation, Atlanta University, Atlanta, Georgia.

[43] Seema, A., \& Sujatha, S. (2015). Impact of mentoring on career success - an empirical study in an indian context. International Journal of Engineering Technology Science and Research, 2(2), 29-48.

[44] Taber, B. J., \& Blankemeyer, M. (2015). Future work self and career adaptability in the prediction of proactive career behaviors. Journal of Vocational Behavior, 86, 20-27.

[45] Tolentino, L. R., James, M. G., Lu, V. N., Restubog, S. L. D., Bordia, P., \& Plewa, C. (2014). Career adaptation: The relation of adaptability to goal orientation, proactive personality, and career optimism. Journal of Vocational Behavior, 84, 39-48.

[46] Tuna M., Kanten P., Yeşiltaş M., Kanten S. \& Alparslan A.M. (2014). The Effect of Academic Advising on Career Adaptabilities: A Study on Tourism and Hotel Management' Students, The Macrotheme Review, 3, 139-155.

[47] Van Vianen, A.E.M., Klehe, U. Koen, J. \& Dries, N. (2012). Career adaptabilities scale Netherlands form: Psychometric properties and relationships to ability, personality, and regulatory focus. Journal of Vocational Behavior, 80 (3), 716-724.

[48] Yousefi, Z., Abedi, M., Baghban, I., Eatemadi, O., \& Abedi, A. (2011). Personal and situational variables, and career concerns: predicting career adaptability in young adults. The Spanish Journal of Psychology, 14(1), 263271.

[49] Zacher, H. (2014). Individual difference predictors of change in career adaptability over time. Journal of Vocational Behavior, 84, 188-198.

[50] Zacher, H. (2015). Daily manifestations of career adaptability: relationships with job and career outcomes. Journal of Vocational Behavior, 91, 76-86.

[51] Zeldin, A. L. (2000). Sources and Effects of the Self-Efficacy Beliefs of Men with Careers in Mathematics, Science, and Technology. Unpublished doctoral dissertation, Emory University, Atlanta, GA. 